\title{
ANALISIS KEBIJAKAN PENANGGULANGAN TUBERKULOSIS (TB) DI KABUPATEN SUKOHARJO MENGGUNAKAN PENDEKATAN GAP ANALYSIS DAN CRITICAL SUCCSESS FACTOR (CSF)
}

\author{
Fahmi Hakam ${ }^{1}$, Nine Elissa Maharani ${ }^{2}$ Prodi. \\ Perekam dan Informasi Kesehatan 1, Prodi. Kesehatan Masyarakat 2 \\ FKM, Universitas Veteran Bangun Nusantara ${ }^{(1,2)}$ \\ Email: fahmihakam01@gmail.com ${ }^{1}, \underline{\text { elissapanjimomo@gmail.com }}^{2}$
}

\begin{abstract}
Sukoharjo is a regency in Central Java that is having high rank of TB case. In 2016, the sufferers of TB were 452 with the total of death were 16 people. In 2017, the sufferers were 335. One of the control indicators was Case Detection Rate (CDR). The established-policy needed medical support facility. The professional employees will support the continuity of health service for the concerned society. The aim of this research was to analyze the rule and fact of TB's tackling in Sukoharjo regency by looking at the side of government organization needs and the plan had made. The approach was needed in examining the plan of strategy and tackling policy by having framework related to the method and systematic technique. The long-term target of this research was the result of the TB's situation analysis that could be the input for the stakeholders dealing with designing the priority scale as the arrangement of Regional Action Plan "Rencana Aksi Daerah (RAD)" or as the advocacy material for civil society group in tackling TB so that its prevention and treatment could be managed and supported by all stakeholders in Sukoharjo regency. The method used by the researcher were GAP Analysis and CSF (Critical Sucses Factor). The cause of the high and low of TB's finding in Sukoharjo regency were categorized into direct and indirect factors. One of them was the absence of special law in regency or regional. The other issue was about human resources. Besides, many health service facilities had not fulfilled the DOTS (Directly Observed Treatment Short-course) which influenced TB's achievement in Sukoharjo regency.

Keywords : Tuberculosis, TB's Policy, CSF, GAP Analysis
\end{abstract}

\begin{abstract}
ABSTRAK
Kabupaten Sukoharjo merupakan kabupaten di Jawa Tengah dengan angka kasus TB yang cenderung tinggi. Pada tahun 2016 penderita TB di Sukoharjo sebesar 452 kasus dengan kematian sebanyak 16 orang. Pada tahun 2017 kasus ini turun menjadi 335 TB. Salah satu indikator untuk pengendalian TB adalah Case Detection Rate (CDR). Kebijakan yang telah ditetapkan tetap membutuhkan dukungan fasilitas kesehatan, tenaga kerja yang profesional dan memadai akan mendukung keberlangsungan pelayanan kesehatan bagi penduduk yang bersangkutan. Tujuan penelitian ini adalah untuk menggali kebijakan dan realita penanggulangan TB di Kabupaten Sukoharjo dengan melihat sisi kebutuhan organisasi pemerintahan dan perencanaan yang dibuat. Dalam mengkaji perencanaan strategi dan kebijakan penanggulangan, diperlukan suatu pendekatan dengan kerangka kerja yang berisi metode dan teknik yang sistematis. Target jangka panjang penelitian ini bahwa hasil laporan anaslsis situasi TB ini dapat menjadi bahan bagi stakeholders terkait untuk membuat skala prioritas, sebagai bahan penyusunan Rencana Aksi Daerah (RAD), maupun sebagai bahan advokasi bagi kelompok masyarakat sipil dalam penangguangan TB di daerah sehingga pencegahan dan pengobatan penyakit TB di Kabupaten Sukoharjo ini dapat dikelola dan didukung semua stakeholders terkait.

Metode yang digunakan peneliti dalam menganalisis kebijakan penanggulangan TB menggunakan GAP Ananlysis dan CSF (Critical Sucses Factor). Penyebab masih tingginya kasus TB dan rendahnya temuan kasus TB di Kabupaten Sukoharjo disebabkan oleh penyebab mendasar, penyebab tidak langsung, dan tidak langsung. Di antaranya adalah belum adanya payung hukum khusus TB di tingkat Kabupaten maupun daerah. Isu lainnya adalah saat ini Kabupaten Sukoharjo masih memiliki masalah terkait SDM. Selain itu masih banyak pula fasyankes yag belum DOTS sehingga akan mempengaruhi pencapaian TB di Kabupaten Sukoharjo.
\end{abstract}

Kata kunci : Tuberkulosis, Kebijakan TB, CSF, GAP 


\section{PENDAHULUAN}

Tuberkulosis (yang selanjutnya disebut TB) adalah penyakit menular yang disebabkan oleh bakteri Mycobacterium tuberculosis. TB merupakan penyebab utama kematian di dunia bersama Human Immunodeficiency Virus (HIV) (WHO 2008). Penanggulangan TB bersama Malaria dan HIV/AIDS menjadi salah satu komitmen global yang terdapat di Sustainable Development Goals (SDGs) yang diadopsi oleh PBB pada 2015 (Chen S 2005).

(WHO 2008) kemudian melaporkan bahwa prevalensi TB tertinggi terdapat di negara-negara Asia Tenggara dan bagian pasifik barat. Indonesia merupakan Negara urutan kedua dengan masalah TB terbesar di dunia setelah India. Jumlah pasien TB di Indonesia mencapai 10\% dari total jumlah pasien TB di dunia pada tahun 2014.

Pada tahun 2015, diperkirakan 6,1 juta kasus baru TB dan 1,4 juta kematian akibat penyakit TB, termasuk 0,4 juta kematian pada orang HIV positif yang berkolaborasi dengan virus TB. Walaupun jumlah kasus TB menurun 22\% dari tahun 2000 hingga 2015, TB masih menjadi satu dari 10 besar penyebab kematian dunia pada tahun 2015. Pada tahun 2015, diestimasikan dari 10,4 juta kasus TB baru terdiri atas 5,9 juta laki-laki, 3,5 juta perempuan, dan 1 juta anak-anak (WHO, 2016). Selain TB dengan HIV (TB HIV), TB dengan diabetes (TB DM) juga menjadi perhatian.

Penderita diabetes memiliki risiko 3 kali lipat lebih besar untuk menderita TB dibandingkan orang pada umumnya sedangkan jumlah penderita diabetes di dunia meningkat setiap tahunnya di mana kejadian terbesar masih didominasi oleh negara berkembang (Kementerian Kesehatan RI 2017).

Departemen Kesehatan RI (2011) melaporkan bahwa setiap tahun terdapat 528.000 kasus dengan angka kematian mencapai 91.000 jiwa yang menyebabkan kerugian ekonomi akibat tuberkulosis cukup besar.

Berdasarkan penelitian yang dilakukan oleh (Li X, Yuan L, Li X, Shi J, Jiang L 2017) peningkatan jumlah kasus yang diobati berdampak besar pada beban ekonomi di suatu daerah. Pada penelitian tersebut dicontohkan satu kasus pada tahun 2011 dimana angka TB yang diobati sebesar $72,7 \%$ apabila angka tersebut meningkat menjadi 92.7\% maka beban ekonomi akan berkurang dari 2.1 miliar USD menjadi 1,3 miliar USD.
Untuk mencapai target program Penanggulangan TB nasional, Pemerintah Daerah provinsi dan Pemerintah Daerah kabupaten/kota harus menetapkan target penanggulangan TB tingkat daerah berdasarkan target nasional dan memperhatikan strategi nasional (Depkes RI 2008).

Penanganan penyakit Tuberculosis (TB) di Kabupaten Sukoharjo sampai saat ini belum dapat dilakukan secara optimal, sebab baru sebagian kecil dari sekian banyak penderita TB yang terdeteksi. Berdasarkan riset Kementrian Kesehatan (Kemenkes) target deteksi penderita TB di Sukoharjo sebanyak 2000an kasus. Sementara pada tahun 2017 baru terdeteksi 336 kasus. Hal ini karena tidak terbukanya masyarakat terhadap penyakit menular tersebut. Salah satu indikator untuk pengendalian TB adalah Case Deyection Rate (CDR).Case Detection Rate merupakan jumlah pasien baru BTA positif yang ditemukan dan diobati terhadap jumlah pasien baru BTA positif yang diperkirakan terdapat di wilayah tersebut. Tahun 2016 kasus TB di Kabupaten Sukoharjo sebesar 452 kasus dengan jumlah kematian sebanyak 16 orang. (Dinkes

Sukoharjo,2016).

Kebijakan yang telah ditetapkan tetap membutuhkan dukungan fasilitas kesehatan yang lengkap, meliputi ketersediaan puskesmas, klinik, dan rumah sakit, alat-alat medis, dan bahan baku medis. Selain fasilitas kesehatan, tenaga kerja yang profesional dan memadai akan mendukung keberlangsungan pelayanan kesehatan bagi penduduk yang bersangkutan.

Dukungan yang telah dipaparkan tersebut merupakan dukungan fisik yang juga membutuhkan dukungan materi berupa ketersediaan dana untuk anggaran rumah sakit, klinik, puskesmas, serta tenaga kerja kesehatan. Analisis kebijakan penanggulangan TB perlu dilakukan untuk mengetahui tingkat keberhasilan dan kesenjangan yang ada.

Salah satu analisis kebijakan yang dapat dilakukan dengan menggunakan GAP Analysis dan Critical Sucses Factor (CSF). GAP analysis digunakan untuk evaluasi yang menitikberatkan pada kesenjangan kinerja saat ini dengan kinerja yang sudah ditargetkan sebelumnya, sedangkan CSF merupakan cara yang digunakan untuk menganalisis faktor penentu sukses usaha/sebuah rencana yang digunakan untuk menyusun struktur kebutuhan informasi pada hierarki manajemen (Retnowati 2004). 


\section{METODE}

Penelitian ini merupakan penelitian Case Study, dengan menggunakan pendekatan kualitatif . Penelitian Case Study merupakan suatu penelitian tindakan yang melibatkan partisipan dalam menganalisis sebuah masalah dan mengetahui kebutuhan, serta menentukan alternatif pemecahan masalah (Creswell,2012).

Analisis situasi TB ini dilakukan dengan model sequencial explanatory. Desain sequencial explanatory melibatkan prosedur pengumpulan data kuantitatif untuk mengeksplorasi penyakit dan program $\mathrm{TB}$, dan kemudian dilakukan pengumpulan data kualitatif untuk menjelaskan dan

\section{HASIL}

Secara astronomis, Kabupaten Sukoharjo terletak di antara 110 57' 33.70" BT Secara administrasi Kabupaten Sukoharjo terbagi menjadi 12 kecamatan yang terdiri dari 167 desa/kelurahan. Luas wilayah Kabupaten Sukoharjo tercatat $46.666 \mathrm{Ha}$ atau sekitar $1,43 \%$ luas wilayah provinsi Jawa Tengah. 7 49' 32.00" LS, pada bagian ujung sebelah timur, $11042^{\prime} 6.79^{\prime \prime}$ BT pada bagian ujung sebelah barat, 7 32' 17.00" LS pada bagian ujung sebelah utara dan pada bagian ujung sebelah selatan.

Kabupaten Sukoharjo merupakan daerah yang memiliki ketinggian antara 90125 meter di atas permukaan air laut, dengan kecamatan tertinggi yaitu kecamatan Polokarto dengan tinggi $125 \mathrm{~m}$ dan kecamatan terendah yaitu Grogol dengan tinggi $93 \mathrm{~m}$ di atas permukaan laut.

Kecamatan Polokarto merupakan kecamatan terluas di Kabupaten Sukoharjo menginterpretasikan lebih lanjut temuan pada data kuantitatif.

Dalam mengkaji perencanaan strategi dan kebijakan penanggulangan, diperlukan suatu pendekatan dengan kerangka kerja yang berisi metode dan teknik yang sistematis. Metode atau kerangka pikir yang digunakan peneliti dalam menganalisis kebijakan penanggulangan TB ini, mengacu pada pendekatan CSF dan Gap Analisys. Penelitian dilakukan pada bulan Juli- September 2018. Penelitian ini dilakukan di Dinas Kesehatan Kabupaten Sukoharjo

yaitu $6.218 \mathrm{Ha}(13 \%)$, sedangkan yang paling kecil adalah Kecamatan Kartasura seluas 1.923 Ha (4\%) dari luas Kabupaten Sukoharjo. Menurut penggunaan lahan terdiri dari lahan sawah sebesar 44,24\% (20.643 Ha) dan lahan bukan sawah sebesar 55,76\% (26.023 Ha). Dari lahan sawah yang mempunyai pengairan teknis seluas $14.692 \mathrm{Ha}(71,17 \%)$, irigasi setengah teknis $2.161 \mathrm{Ha}(10,47 \%)$, irigasi sederhana $1.944 \mathrm{Ha}(9,42 \%)$ dan tadah hujan seluas $1.846 \mathrm{Ha}(8,94 \%)$.

Kabupaten Sukoharjo sebagai salah satu Kabupaten di Jawa Tengah, terletak di antara 6 kabupaten/kota yaitu di sebelah utara berbatasan dengan kota Surakarta dan Kabupaten Karanganyar, di sebelah timur berbatasan dengan Kabupaten Karanganyar, sebelah selatan berbatasan dengan Kabupaten Gunung Kidul dan Kabupaten Wonogiri serta sebelah barat berbatasan dengan Kabupaten Klaten dan Kabupaten Boyolali. 


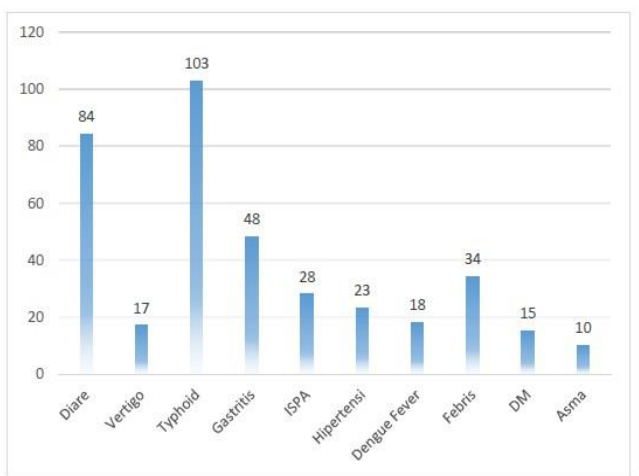

Gambar 2. Daftar 10 Besar Penyakit

Terbanyak di Kab. Sukoharjo Tahun 2016

Grafik di atas menunjukkan 10 besar penyakit terbanyak di Kab. Sukoharjo tahun 2016. Tampak penyakit terbanyak yaitu Demam

Typhoid sebanyak 103 kasus. Selanjutnya adalah Diare dengan jumlah 84 kasus. Penyakit lainnya yaitu Gastritis dengan 48 kasus, Febris dengan 34 kasus, Ispa dengan 28 kasus, Hipertensi dengan 23 kasus, Demam Dengue dengan 18 kasus, Vertigo dengan 17 kasus, DM dengan 15 kasus, dan Asma dengan 10 kasus. Data ini diperoleh dari staf Dinas Kesehatan Kabupaten Sukoharjo.

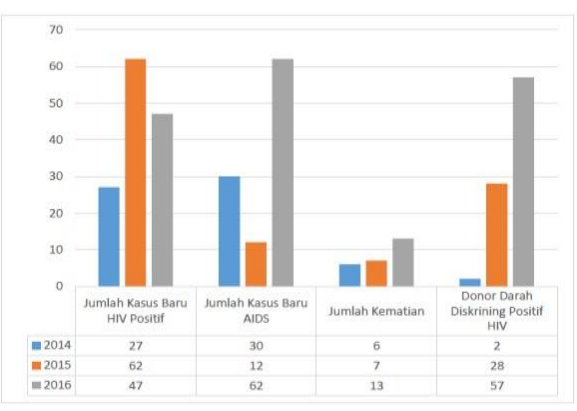

Gambar 3. Jumlah Penderita HIV/AIDS di Kab. Sukoharjo Tahun 2014-2016

Jumlah total kasus HIV/AIDS dari tahun 2014-2016 jumlahnya cenderung meningkat. Jumlah kasus baru HIV tahun 2014 sebanyak 27 kasus, 2015 sebanyak 62 kasus, dan 2016 sebanyak 47 kasus. Jumlah kasus baru AIDS tahun 2014 sebanyak 30 kasus, 2015 sebanyak 12 kasus, dan 2016 sebanyak 62 kasus. Jumlah kematian akibat HIV/AIDS di Kabupaten Sukoharjo juga mengalami peningkatan dari tahun 2014-2016. Tren yang sama juga terjadi pada kategori HIV positif yang terdeteksi pada saat donor.

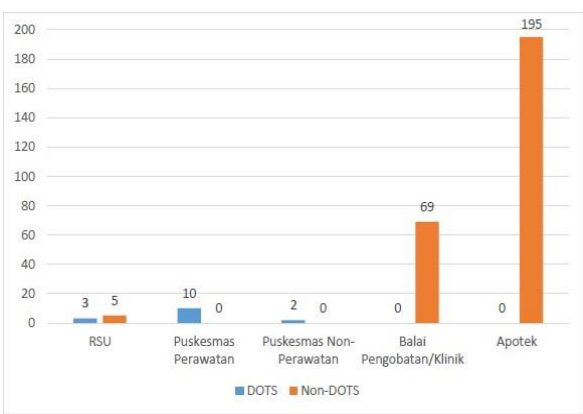

Gambar 4. Jumlah Fasyankes DOTS dan NonDOTS di Kab. Sukoharjo Tahun 2016

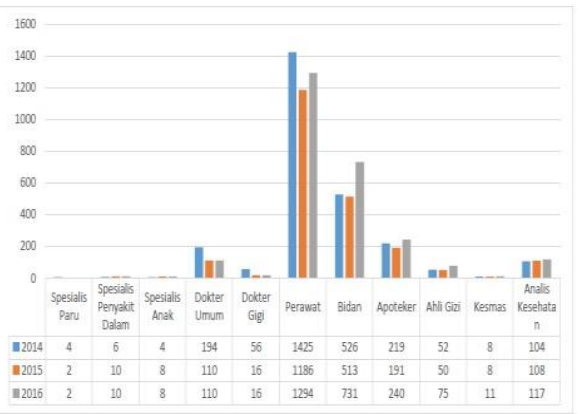

Gambar 5. Jumlah Tenaga Kesehatan Di. Kab. Sukoharjo Tahun 2016

Jumlah tenaga kesehatan paling banyak di Kabupaten Sukoharjo adalah perawat dengan jumlah 1.294 orang pada tahun 2016. Jumlah dokter umum adalah 194 pada tahun 2014, berkurang menjadi 110 dokter umum pada tahun 2015, dan tetap 110 dokter pada 2016. Dokter spesialis paru pada tahun 2014 sebanyak 4 orang, pada tahun 2015 berkurang setengahnya menjadi 2 orang. Jumlah dokter spesialis paru pada tahun 2016 sama dengan tahun 2015, yaitu sebanyak 2 orang.

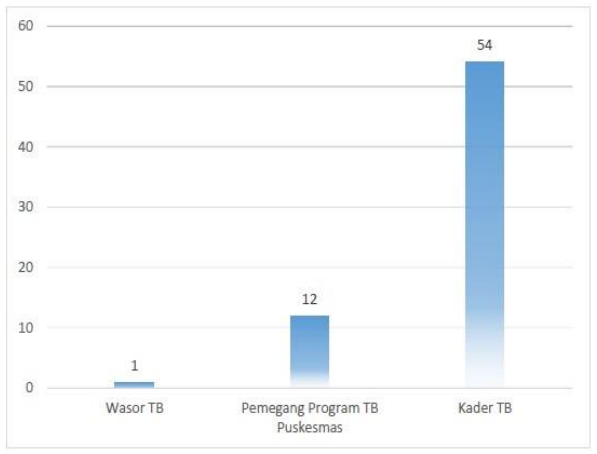

Gambar 6. Jumlah Tenaga Kesehatan TB di Kab. Sukoharjo Tahun 2016 
Terdapat 1 orang Wakil Supervisor (wasor) TB di Kabupaten Sukoharjo pada tahun. Jumlah pemegang program TB di PKM 12, masing-masing 1 orang untuk tiap puskesmas. Sedangkan untuk kader TB, baik gabungan dari kader yang dimiliki LSM maupun bentukan puskesmas jumlahya kurang lebih 54 orang.

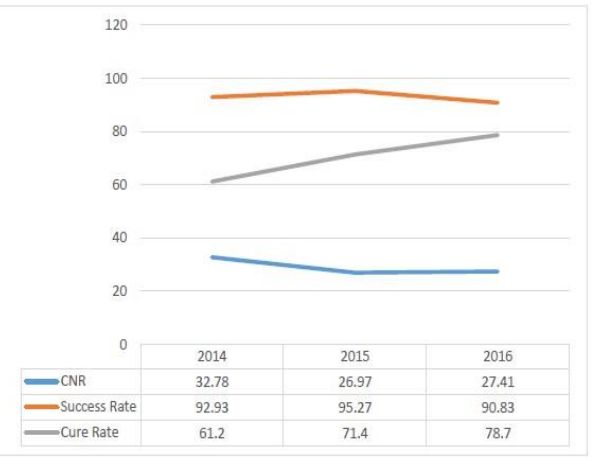

Gambar 7. Target Indikator TB Kab. Sukoharjo Tahun 2016

Case Notification Rate (CNR) adalah angka yang menunjukkan jumlah pasien baru yang ditemukan dan tercatat di antara 100.000 penduduk di suatu wilayah tertentu. Succes Rate adalah jumlah pasien TB yang menyelesaikan pengobatannya. Cure rate atau angka kesembuhan yang didefinisikan sebagai angka yang menunjukkan persentase pasien baru TB paru BTA positif yang sembuh setelah selesai masa pengobatan, diantara pasien baru TB paru BTA positif yang tercatat. Grafik di atas menunjukkan target-target Kabupaten Sukoharjo untuk penanggulangan TB. Case Notification Rate (CNR) pada tahun 2016 adalah 27,41; Success Rate 90,83\%; dan Cure rate $78,7 \%$.

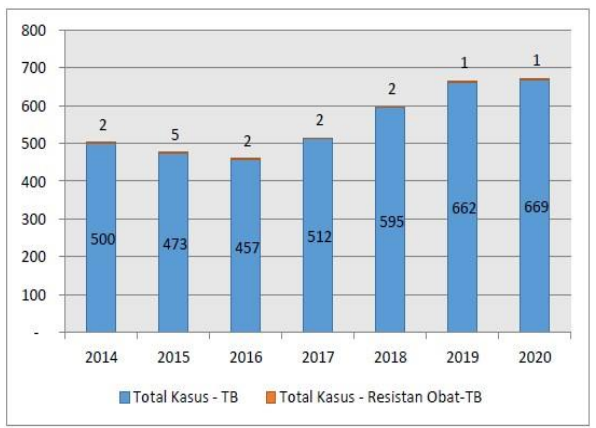

Gambar 8. Kasus TB dan TB Resisten Obat di Kabupaten Sukoharjo 2014-2020
Gambar di atas menunjukkan total kasus TB Reguler dan TB Resisten Obat. Pada kasus aktual, TB Reguler mengalami tren penurunan sejak tahun 2014 hingga 2016, dimana terdapat 500 kasus pada tahun 2014, 473 kasus pada tahun 2015, dan 457 kasus pada tahun 2016. Sementara untuk TB Resisten Obat pada tahun 2014 tercatat 2 kasus, tahun 2015 terdapat 5 kasus, dan 2016 terdapat 2 kasus TB Resisten Obat.

Data tahun 2017-2020 merupakan proyeksi. Untuk proyeksi, Penemuan kasus (CNR) pada tahun 2017 sesuai dengan target Kementerian Kesehatan RI yaitu 122 per 100.000 penduduk, CNR tahun 2018 mengalami kenaikan $16 \%$, tahun 2019 meningkat $11 \%$, dan tahun 2020 mengalami kenaikan sebesar $1 \%$.

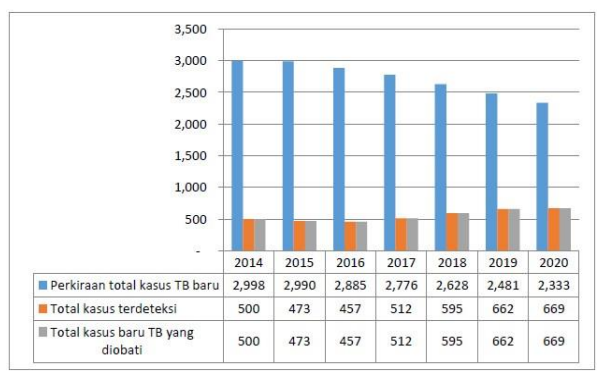

Gambar 9. Data kasus DSTB di Kabupaten Sukoharjo Tahun 2014-2020

Gambar di atas menunjukkan adanya selisih yang besar antara estimasi perkiraan kasus TB baru dan kasus TB yang ditemukan oleh Kabupaten Sukoharjo. Pada tahun 2016 misalnya, dari estimasi 2.885 kasus baru, jumlah kasus yang ditemukan adalah 457 kasus. Semua kasus yang ditemukan selanjutnya diberikan pengobatan. Perkiraan insidensi TB didapatkan dari Survey Prevalensi Nasional Kementerian Kesehatan Republik Indonesia.

Untuk tahun 2018-2020 yang merupakan proyeksi, menggunakan asumsi insidensi menurun $3 \%$ di tahun $2018,4 \%$ di tahun 2019 , dan $6 \%$ di tahun 2020, sesuai dengan treninsidensi nasional. Sedangkan total kasus terdeteksi TB didapatkan dari laporan SITT TB 07 tahun 2014-2016. Semua kasus yang ditemukan dan tercatat dilakukan pengobatan menggunakan standart DOTS. 


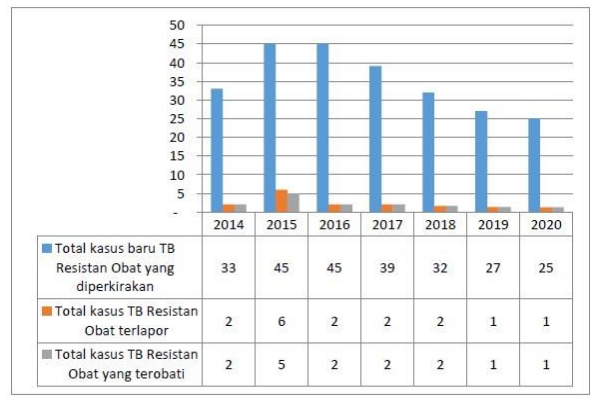

Gambar 10. Temuan Kasus Baru TB dan TB

Resisten Obat di Kabupaten Sukoharjo Tahun 2014-2020

Gambar di atas juga menunjukkan adanya selisih yang cukup banyak antara estimasi kasus TB RO dan juga kasus TB RO yang ditemukan. Tahun 2014 kasus TB RO yang diperkirakan adalah sebanyak 33 kasus dan yang ditemukan sebanyak 2 kasus. Tahun 2015 kasus TB RO yang diperkirakan adalah sebanyak 45 kasus, sedangkan yang ditemukan hanya 6 kasus. Tahun 2016 selisinya semakin banyak, yakni diperkirakan terdapat 45 kasus, namun yang ditemukan hanya 2 kasus.

Perkiraan jumlah kasus TB resisten obat tahun 2014 didapatkan dari rujukan WHO yang menyatakan bahwa TB resisten obat berasal dari 1,9\% kasus baru ditambah $12 \%$ kasus pengobatan ulang. Untuk perkiraan kasus TB resisten obat tahun 2015 dan 2016 juga dari penelitian WHO yang mana 2,8\% kasus baru dan 16\% kasus pengobatan ulang adalah TB resisten obat. Asumsi yang sama juga digunakan untuk proyeksi kasus baru TB RO pada tahun 2017 hingga tahun 2020. Proyeksi TB RO yang ditemukan dan diobati diasumsikan memiliki persentase yang sama dengan tahun 2016 sebagai baseline.

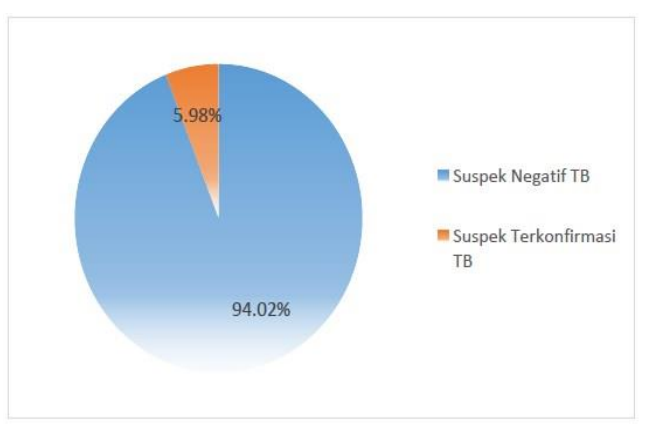

Gambar 11. Temuan Kasus Kader 'Aisyiyah Kab. Sukoharjo tahun 2017
Peran Kader 'Aisyiyah dalam penemuan kasus baru di sebuah kabupaten/kota sangatlah penting, termasuk di Kabupaten Sukoharjo. Grafik di atas menunjukkan capaian temuan kasus TB yang dilakukan oleh kader 'Aisyiyah Kabupaten Sukoharjo. Data di atas adalah hasil dari Kegiatan yang dimulai dari Bulan Januari 2017-Agustus 2017. Suspek TB yang diperiksakan adalah sebanyak 736, dan jumlah pasien yang terkonfirmasi TB sebanyak 44 pasien. Persentase kasus yang terkonfirmasi adalah sebesar 5,98\%. Kader 'Aisyiyah dalam SSR 'Aisyiyah di Kabupaten Sukoharjo baru terbentuk pada akhir tahun 2016, sehingga pencatatan dan kegiatan yang dilakukan barulah di tahun 2017.

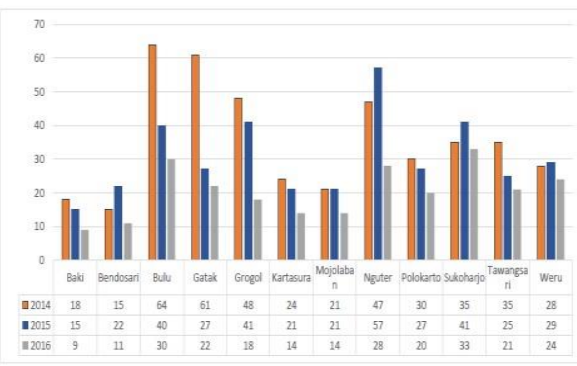

Gambar 12. Temuan Kasus TB per

Kecamatan di Kabupaten Sukoharjo Tahun 2014-2016

Gambar di atas menunjukkan jumlah kasus TB terbanyak pada tahun 2014 terdapat di Kecamatan Bulu dengan 64 kasus. Tahun 2015 kasus terbanyak terdapat di Kecamatan Nguter dengan 57 kasus. Tahun 2016 kasus terbanyak terdapat di Kecamatan Sukoharjo dengan 33 kasus.

Grafik di atas menunjukkan sebagian besar penderita TB di Kabupaten Sukoharjo pada tahun 2016 diderita oleh kelompok usia 0-14 tahun. Selanjutnya adalah kelompok usia 25-34 tahun dan 34-44 tahun yang masing-masing berjumlah 70 orang. Kelompok usia 55-64 tahun berjumlah 69 orang, kelompok usia 45-54 tahun berjumlah 67 kasus, kelompok usia $>60$ tahun 63 kasus, dan yang paling sedikit adalah kelompok usia 15-24 tahun dengan jumlah 35 orang. Data di atas masih merupakan data untuk 1 semester saja. 


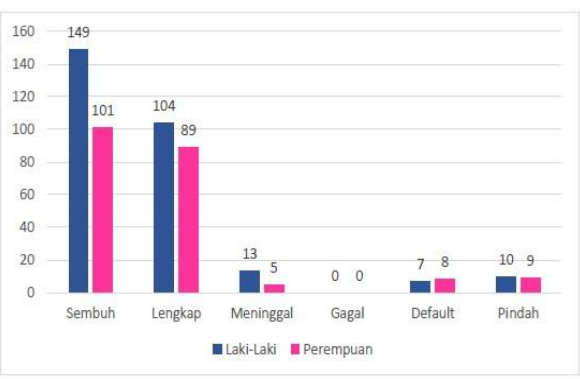

Gambar 13. Jumlah Kasus TB Berdasarkan Jenis Kelamin di Kabupaten Sukoharjo tahun 2016

Sebagian besar Penderita TB di Kabupaten Sukoharjo berjenis kelamin laki-laki. Sebagian besar kategori kasus, yakni sembuh, lengkap, meninggal, dan pindah didominasi oleh lakilaki, kecuali pada kategori default dimana jumlah perempuan sedikit lebih banyak, yakni 8 orang, sedangkan laki-laki berjumlah 7 orang.

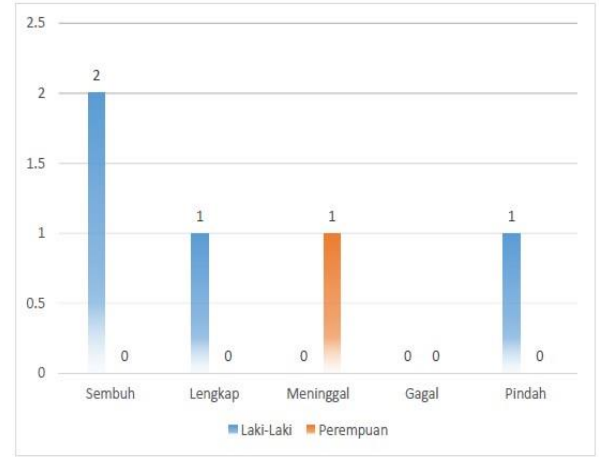

Gambar 14. Data Pasien TB dengan HIV di Kab. Sukoharjo Tahun 2016

Data di atas menunjukkan data pasien HIV/AIDS yang mengidap TB tahun 2016 berdasarkan hasil pengobatan yang diberikan. Tampak jumlah pasien yang sembuh pada tahun 2016 sebanyak 2 orang dan kesemuanya berjenis kelamin laki- laki. Jumlah pasien yang telah lengkap menyelesaikan pengobatan sebanyak 1 orang dan berjenis kelamin laki-laki. Jumlah yang meninggal sebanyak 1 pasien dan berjenis kelamin perempuan, dan yang pindah adalah seorang laki-laki.

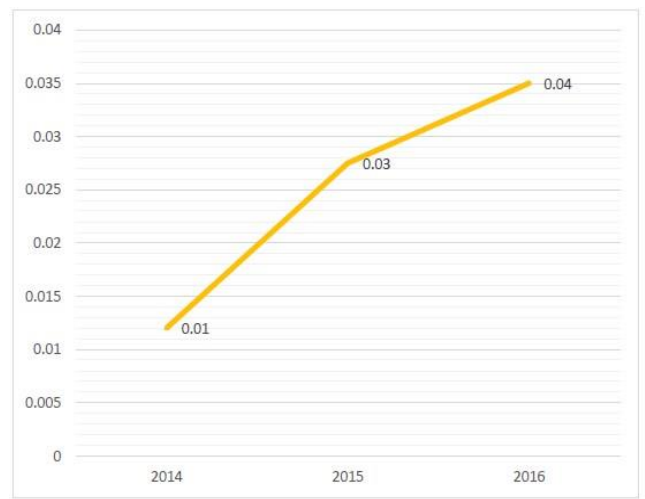

Gambar 15 Case Fatality Rate (CFR) TB di Kab. Sukoharjo Tahun 2014-2016

TB merupakan penyakit yang memerlukan pengobatan efektif dalam jangka waktu tertentu. Apabila pengobatan tidak berhasil, maka dapat mengakibatkan kematian karena TB. Gambar di atas menggambarkan Case Fatality Rate (CFR) TB di Kabupaten Sukoharjo. CFR menunjukkan persentase jumlah kematian TB dari jumlah seluruh kasus TB pada periode waku tertentu.

Berdasarkan gambar di atas, pada tahun 2014 CFR TB adalah $0,01 \%$ atau 6 kematian dari seluruh kasus TB, sedangkan pada tahun 2015 CFR TB sebesar $0,03 \%$ atau 13 kematian dari seluruh kasus, dan tahun 2016 CFR TB adalah 0,04\% atau 16 kematian dari seluruh kasus TB.

\section{PEMBAHASAN}

DOTS (Directly Observed Treatment Shortcourse) merupakan strategi pengendalian TB yang direkomendasikan oleh WHO. DOTS diharapkan akan diterapkan oleh semua tenaga kesehatan baik itu dari FKTP maupun FKRTL. Di Indonesia strategi DOTS ini sudah dijalankan sejak tahun 1995. Namun, strategi ini belum mencapai target keberhasilan pengobatan yang ditetapkan oleh Kementerian Kesehatan yaitu Succes Rate 90\% dan Cure Rate mencapai $85 \%$ dari penderita TB dengan BTA (+) yang diobati. Salah satu kendala belum tercapainya keberhasilan pengobatan TB adalah kondisi fasilitas kesehatan. Di Kabupaten Sukoharjo, sebagian besar fasyankes masih belum DOTS. Dalam program penanggulangan $\mathrm{TB}$ dalam strategi nasional untuk memberikan akses menyeluruh kepada masyarakat, maka diharapkan adanya Public-Private Mix (PPM) dalam pelaksanaan program DOTS. Maksud dari 
PPM ini yaitu adanya keterlibatan pihak swasta, LSM, hubungan lintas sektor, organisasi profesi dalam penanggulangan TB ini (Kementerian Kesehatan, 2014). Salah satu contoh PPM yaitu pelaksanaan DOTS di klinik-klinik swasta dan dokter praktik mandiri. Hal tersebut belum berjalan di Kabupaten Sukoharjo karena semua klinik swasta dan dokter praktik mandiri di Kabupaten Sukoharjo belum terintegrasi dengan DOTS. Bentuk PPM lainnya yaitu adanya pemberdayaan terhadap seluruh lapisan masyarakat melalui pengkaderan. Peran kader ini sangat penting, yaitu untu menjangkau masyarakat yang belum terjangkau oleh tenaga kesehatan. Masih ada beberapa puskesmas yang belum memiliki kader.

Selain kader dari PPK dan kader yang dibentuk oleh puskesmas, terdapat pula kader yang dikelola 'Aisyiyah sebanyak yang tersebar di beberapa kecamatan di Kabupaten Sukoharjo. Kader 'Aisyiyah memiliki peran yang sangat penting di sebuah daerah, termasuk Kabupaten Sukoharjo. Peran kader yang langsung bersentuhan dengan masyarakat, menjaring

langsung, bahkan memiliki tugas mendampingi pengobatan pasien akan sangat membantu penemuan kasus dan juga keberhasilan pengobatan soerang pasien. Peran kader yang sangat penting inilah yang harus dilanjutkan oleh 'Asiyiyah secara khusus dengan meningkatkan kulaitas dan kuantitas kader, maupun oleh Pemerintah Daerah secara umum, agar dilakukan kolaborasi secara rutin antara Pemda dan SSR TB- HIV 'Aisyiyah.

Kondisi Sumber Daya Manusia (SDM) hingga saat ini masih dirasakan menjadi masalah di Kabupaten Sukoharjo. Salah satu permasalahannya adalah rangkap jabatan ataupun tanggungjawab seorang SDM TB. Dengan rangkap posisi dan tanggung jawab ini akan mengganggu fokus SDM tersebut untuk program TB. Seperti yang kita ketahui bersama bahwa penanggulangan TB sangat memerlukan keaktifan untuk melakukan penemuan kasus. Semakin banyak suspek yang diperiksa akan semakin baik. Dengan rangkap posisi dan tanggungjawab ini akan mengurangi keaktifan seorang SDM, karena perlu mengurusi program lain pula. Makin banyak rangkap posisi yang diemban, maka akan berkurang keaktifan SDM tersebut dalam tanggung jawabnya di program TB. Selain itu sulitnya kaderisasi juga perlu menjadi perhatian khususnya bagi Dinas Kesehatan. Sulitnya regenerasi SDM akan menghambat sustainabilitas suatu program, dan tentunya akan berdampak pada kurang baiknya pencapaian program tersebut.
Masih terkait SDM, jumlah tenaga kesehatan yang berhubungan dengan TB seperti dokter spesialis paru masih kurang. Pada tahun 2016, Kabupaten Sukoharjo hanya memiliki 2 orang dokter spesialis paru. Pada tahun yang sama, dari 8 RSU, Kabupaten Sukoharjo memiliki 3 rumah sakit yang telah memberikan pelayanan berdasarkan standar DOTS, dan direncakan tahun 2018 akan bertambah 1 sehingga menjadi 4 RS yang melayani DOTS. Menurut Kementerian Kesehatan (2014), tiap rumah sakit yang melaksanakan DOTS, setidaknya tipe $\mathrm{C}$ atau diatasnya memiliki setidaknya 1 orang dokter spesialis paru, karena mengingat fungsi rumah sakit juga sebagai rujukan kasus TB dengan komplikasi. Karena hal tersebut, diketahui bahwa Kabupaten Sukoharjo kekurangan dokter spesialis paru. Jumlah analis kesehatan di Kabupaten Sukoharjo pada tahun 2016 berjumlah 117 orang. Standarisasi Puskesmas rujukan mikroskopis dan puskesmas pelaksana mandiri setidaknya harus memiliki 1 orang analis kesehatan (Kementerian Kesehatan, 2014). Hingga saat ini Kabupaten Sukoharjo memiliki 1 orang wasor TB dan memiliki 3 Rumah Sakit DOTS dan 12 Puskesmas yang sudah DOTS pula. Artinya 1 orang wasor tersebut mengelola 15 fasyankes DOTS. Menurut Kementerian Kesehatan (2014), apabila wasor daerah membawahi lebih 20 fasyankes, maka dapat memiliki lebih dari seorang wakil supervisor. Untuk itu, saat ini komposisi wasor dan fasyankes dengan perbandingan 1:15 sudah termasuk ideal.

Sebagian besar penderita TB di Kabupaten Sukoharjo pada tahun 2016 adalah pada usia-usia produktif (Gambar 25). Usia produktif merupakan usia dimana seseorang berada pada tahap untuk bekerja/menghasilkan sesuatu baik untuk diri sendiri maupun orang lain. Apabila seseorang menderita TB pada usia tersebut, maka dapat menghambat produktivitas bahkan menjadi beban bagi keluarga dan masyarakat. Berdasarkan TB economic burden tools, seorang pasien TB dan TB-RO yang tidak terobati diperkirakan tidak dapat bekerja selama 144 hari per tahun dan tak jarang menyebabkan kematian pada usia muda. Hal ini merugikan secara ekonomis dan akan menyebabkan beban ekonomi meningkat, terutama pada komponen hilang produktivitas karena cacat dan kematian dini karena TB (Tabel 2).

TB merupakan penyakit yang bisa dicegah dan disembuhkan, sehingga seharusnya 
angka kematian TB bisa ditekan. Angka kematian TB dari seluruh kasus (CFR) di Kabupaten Sukoharjo dalam 3 tahun terus meningkat (Gambar 28). Salah satu faktor risiko kematian karena TB adalah pengobatan yang tidak adekuat yang dapat dilihat dari indikator success rate dan cure rate pengobatan $\mathrm{TB}$ (Kementerian Kesehatan RI, 2014). Hingga tahun 2016, meski jumlah pasien yang menyelesaikan pengobatan sudah sesuai target, namun angka kesembuhan TB di Kabupaten Sukoharjo masih belum mencapai target nasional sehingga perlu ada upaya untuk meningkatkannya. Salah satu contohnya adalah perlunya pengawasan yang lebih baik lagi selama pasien menjalani pengobatan, perlunya pemberian makanan tambahan yang lebih bergizi, dan motivasi lebih lagi kepada pasien. Faktor risiko lain penyebab kematian karena TB menurut Kementerian Kesehatan RI (2014) adalah akibat keterlambatan diagnosis dan adanya penyakit penyerta (komorbiditas), contohnya pasien TB dengan HIV atau DM.

Tingkat daya tahan tubuh seseorang akan berpengaruh pada faktor risiko penularan TB. Individu dengan daya tahan tubuh yang rendah, seperti pada penderita gizi buruk atau HIV/AIDS, lebih rentan terhadap penyakit TB. Semakin bertambahnya jumlah kasus HIV/AIDS akan menyebabkan jumlah kasus TB meningkat pula karena TB merupakan infeksi oportunistik terbanyak pada ODHA (Kementerian Kesehatan RI, 2011). Pasien TB dengan HIV positif dan ODHA dengan TB disebut sebagai pasien koinfeksi. Koinfeksi TB-HIV memerlukan penanganan yang komprehensif, baik dalam hal diagnosis, pengobatan, pencegahan maupun penanganan komplikasi berupa TB-RO. Pasien TB yang tidak terobati akan meningkatkan risiko kematian dan risiko ini meningkat pada pasien koefisiensi TB-HIV (Kementerian Kesehatan RI, 2014).

Penyebab langsung permasalahan TB dan rendahnya pencapaian di Kabupaten Sukoharjo adalah kurangnya SDM, kurangnya sarana dan prasanana, pengetahuan masyarakat dalam pencegahan dan penanganan TB masih rendah, sosialisasi pemerintah dalam penangana TB masih rendah, dan tidak adanya kebijakan dan peraturan khusus yang ditetapkan oleh pemerintah daerah atau kabupaten.
Penyebab mendasar dan tidak langsung kemudian akan menjadi penyebab langsung yaitu penemuan kasus baru TB diakibatkan penularan dari penderita TB (termasuk kader dan PMO yang berisiko tinggi untuk tertular); pemahaman masyarakat kurang tentang proses penularan TB; pasien TB tidak rutin dalam melakukan pemeriksaan; pasien gejala TB tidak terbuka dalam memberikan informasi; dan pada akhirnya juga akan berefek pada laporan perkembangan pasien tidak terekam dengan baik meskipun penyebab terkait pencatatan laporan perkembagan ini tidak ditemukan saat dilakukan RTD maupun in-depth interview.

Untuk mencapai Kabupaten Sukoharjo bebas TB tahun 2050 seperti yang ditargetkan Kementerian Kesehatan RI, memang tidak mudah mengingat hingga saat ini angka temuan TB di Kabupaten Sukoharjo hingga saat ini masih rendah jika dibandingkan target nasional. Tahun 2016 CNR hanya 27,41\%. Oleh karena itu, diperlukan kerja keras dari semua lapisan masyarakat. Adapun upaya yang bisa dilakukan pada saat ini oleh Kabupaten Sukoharjo adalah mengatasi penyebab dasar yang diperkuat dengan adanya kebijakan atau peraturan khusus TB di tingkat kabupaten. Kerjasama lintas sektor dalam program penanggulangan $\mathrm{TB}$ di Kabupaten Sukoharjo sangat penting. Tabel di bawah ini adalah potensi yang bisa dikembangkan oleh stakeholders terkait yang dapat membantu program penganggulangan TB.

Hal lain yang didapatkan dari indepth interview adalah tenaga kesehatan, khususnya dokter dan perawat yang menangani pasien secara langsung memiliki peran yang sangat penting dalam memberikan pengetahuan tentang TB kepada pasien. Dari dua informan yang diwawancarai, mereka mengaku bahwa selama ini mereka belum pernah mendaptkan sosialisasi tentang TB, baik dari Puskesmas maupun Dinas Kesehatan, meskipun Puskesmas menyatakan bahwa Puskesmas melakukan sosialisasi.

Dirasakan pula bahwa tidak ada stigma ataupun diskriminasi yang diterima pasien, hal ini diketahui dari in-depth interview dengan kedua responden ini. Yang dirasakan malah sebaliknya, yaitu lingkungan sekitarnya memberikan dukungan dan semangat agar responden menyelesaikan pengobatan dan sembuh. Bahkan keluarga juga mendukung serta setiap hari mengingatkan minum obat. 


\section{SIMPULAN}

\begin{tabular}{lll}
\multicolumn{1}{c}{ Dari } & analisis & situasi yang sudah \\
dilakukan & di & Kabupaten Sukoharjo \\
dapat disimpulkan & bahwa temuan kasus
\end{tabular}
TB di Kabupaten Sukoharjo hingga tahun 2016 masih rendah. Penyebab masih tingginya kasus TB dan rendahnya temuan kasus TB di Kabupaten Sukoharjo disebabkan oleh penyebab mendasar, penyebab tidak langsung, dan tidak langsung. Di antaranya adalah belum adanya payung hukum khusus TB di tingkat Kabupaten maupun daerah. Isu lainnya adalah saat ini Kabupaten Sukoharjo masih memiliki masalah terkait SDM. Selain itu masih banyak pula fasyankes yag belum DOTS sehingga akan mempengaruhi pencapaian TB di Kabupaten Sukoharjo.

Dilihat dari segi ekonomi, TB membebani Kabupaten Sukoharjo secara ekonomi. Apabila Kabupaten Sukoharjo menginvestasikan dana untuk biaya pelayanan medis kasus TB sebesar kurang lebih Rp 2,2 miliar, maka dapat menghemat total biaya sekitar Rp 31,3 miliar. Untuk mencapai Kabupaten Sukoharjo bebas TB perlu peran serta aktif seluruh lapisan pemerintahan dan masyarakat di Kabupaten Sukoharjo, dan disepakati pula bahwa perlu adanya payung hukum dalam penanggulangan TB di Kabupaten Sukoharjo.

\section{DAFTAR PUSTAKA}

Altemimi, M.A.H., Zakaria, M.S. \& Mahmood, A.K., 2012. Assessing the Performance of Information Technology Strategic Planning for Organization Using Performance Measurement Framework. In International Conference on Computer \& Information Science (ICCIS). IEEE, pp. 164-169.

Chen J CM, Chen S, Z.S., 2005. Community Environment and HIV/AIDS Related Stigma in China. AIDS Educ Prev, 2005;17(1).

Creswell, J.W., 2012. Educational Research Fourth Edi., Boston: PEARSON Publisher.

David, F.., 2006. Manajemen Strategis: Konsep 10th ed., Jakarta: Salemba Empat.

Depkes RI, 2014. Laporan Pengembangan HIV/AIDS tahun 2014, Jakarta, Indonesia.

Depkes RI, 2008. Pedoman Nasional Penanggulangan Tuberkulosis Edisi 2.,
Jakarta.

Gede, M., 1999. AIDS di Indonesia Masalah dan Kebijakannya Cetakan I., Jakarta: EGC.

Hakam, F. (2016). Analisis, Perancangan dan Evaluasi Sistem Informasi Kesehatan. Yogyakarta: Gosyen Publishing

Hakam, F. (2017). Rencana Strategis Sistem Informasi dan Teknologi Informasi (RENSTRA SI-TI) Rumah Sakit. Yogyakarta: TEKNOSAIN (CV. Graha Ilmu)

Kaplan, R.S. \& David P, N., 1996. The Balanced Scorecard.

Kementerian Kesehatan RI, 2017. Laporan HIV/AIDS Triwulan I Tahun 2017, Jakarta.

Li X, Yuan L, Li X, Shi J, Jiang L, Z.C., 2017. Factors Associated with Stigma Attitude Towards People Living with HIV Among General Individuals in Heilongjiang,Northeast China. $B M C$ Infectious Diseases, (2017) 17:

Nasir, S., 2005. The development change and transformation of management information system (MIS): A Content analysis of articles published in business and marketing journal. International journal of information management, 25, pp.442-457.

Retnowati, N.D., 2004. Analisis CSF , SWOT dan TOWS Studi Kasus : PT Intan Pariwara Klaten., pp.31-37.

WHO, 2008. Global Tuberculosis Control, Surveilance, Planning, Financing,

Yang, J., 2009. A Balanced Performance Measurement Scorecard Approach for Product Service Systems. In International Conference on Business Intelligence and Financial Engineering. Beijing: IEEE.

Yin, R.., 2012. Studi Kasus Desain dan Metode 11 th., Jakarta: Raja Grafindo Persada. 